\title{
The effectiveness of CFRP strengthening of steel plate girders with web opening subjected to shear
}

\author{
Mohammed Hamood ${ }^{1, *}$, Wael AbdulSahib ${ }^{1}$, and Ali Abdullah ${ }^{1}$ \\ ${ }^{1}$ Building and Construction Engineering Department, University of Technology, Baghdad, Iraq
}

\begin{abstract}
The present study is experimental by nature; it involves applying shear buckling test on seven steel-plated girders that are subjected to shear loading. Four of these girders represent the strengthened girders whereas the other three are reference girders. One of the latter type of girders has a square web opening; the second has a diamond web opening while the last one has no opening at all. The webs of the strengthened girders were adhesively attached to CFRP sheets of different patterns. This step was carried out to evaluate the most effective strengthening scheme by CFRP composite. The study aims at examining the effect of several parameters on the behavior of web girders. It further examines the percentage of increase in the ultimate shear capacity of the perforated girders that have a fixed location and size where the latter is equal to 40 percent of the web depth. Results have shown that, first, the ultimate shear load of the CFRP-strengthened girders with square web opening is higher than that of the reference girder with a square web opening; ranging from $8.7 \%$ to $15.7 \%$. The obtained ranges depend on the orientation of the CFRP strips. Second, the ultimate shear load of the CFRP-strengthened girders with a diamond web opening is higher than the reference girder with a range of $9.8 \%$ to $21.5 \%$. Again, the obtained ranges depend on the orientation of the CFRP strips. Analytically speaking, Von Mises stresses have been used to predict the ultimate shear load of girders with square and diamond web openings and without web opening.
\end{abstract}

\section{Introduction}

Many research studies have been so far conducted on the use of carbon fiber reinforced plastic composite in both strengthening and repairing the webs of girders. These previously conducted studies mainly focused on the application of CFRP to girders with axial or bending stresses. As far as the investigations on strengthening and repairing web girders using CFRP are concerned, they have been reported few.

The standard strengthening techniques used with steel-plated girders include bolting or welding. However, these techniques are not void of disadvantages; cases in point are the effect of corrosion, the fatigue-sensitivity of the repaired system to the stress concentration resulted from either the bolting or welding techniques. Another shortcoming is the long period of service interruption. Recently, alternative girder strengthening techniques have been used, such as that of the external bonded (CFRP) composites. Such techniques help prevent web buckling in steel-plated girders by adding stiffness to the web of girder. In other words, the stiffness of CFRP provides the required high stiffness, tensile strength and corrosion /fatigue resistance to the girders $[1,2,3,4]$.

In modern buildings and bridges, large ducts for aircondition system, sanitary pipes, sewage pipes, electric cables and other services need to be provided. However, to provide such services, an unacceptably large construction depth between storeys is needed. To solve this problem, a web opening needs to be made on each of the web girders. This helps in extending the pipes of services and reducing the floor height. However, such web openings change the distribution of stress at the web of girders and ultimately reduce the shear and bending strength capacity of the girder $[2,3,4]$.

To restore the lost strength, the locations of these openings and the lost strength need first to be studied and measured, respectively. Second, the lost strength in these locations and the locations surrounding the openings needs to be strengthened with different patterns of CFRP. In addition to that, one should avoid making such openings in locations where the shear stresses are high [5].

\section{Material properties}

The properties of the materials used in the tested plate girders include the following:

\subsection{Stee}

Table (1), below, shows the details and properties of the steel plates used to form the seven steel-plated girders obtained from the Tensile strength test, as shown in Figure (1). In this study, the modules of elasticity and poison's ratio are assumed to be $200000 \mathrm{MPa}$ and 0.3 respectively:

Corresponding author: mjh_smm@yahoo.com 
Table 1. Properties of Steel Plates Used for Girders

\begin{tabular}{|c|c|c|c|c|c|}
\hline Component & $\begin{array}{c}\text { Thickness } \\
(\mathrm{mm})\end{array}$ & \multicolumn{2}{|c|}{$\sigma y(\mathrm{MPa})$} & \multicolumn{2}{|c|}{ бu (MPa) } \\
\hline \multirow{3}{*}{$\begin{array}{l}\text { Flange/ } \\
\text { stiffeners }\end{array}$} & \multirow{3}{*}{10} & 255 & \multirow{3}{*}{255} & 400 & \multirow{3}{*}{403} \\
\hline & & 255 & & 405 & \\
\hline & & 255 & & 404 & \\
\hline \multirow{3}{*}{ web } & \multirow{3}{*}{2} & 250 & \multirow{3}{*}{260} & 365 & \multirow{3}{*}{370} \\
\hline & & 270 & & 375 & \\
\hline & & 260 & & 370 & \\
\hline
\end{tabular}
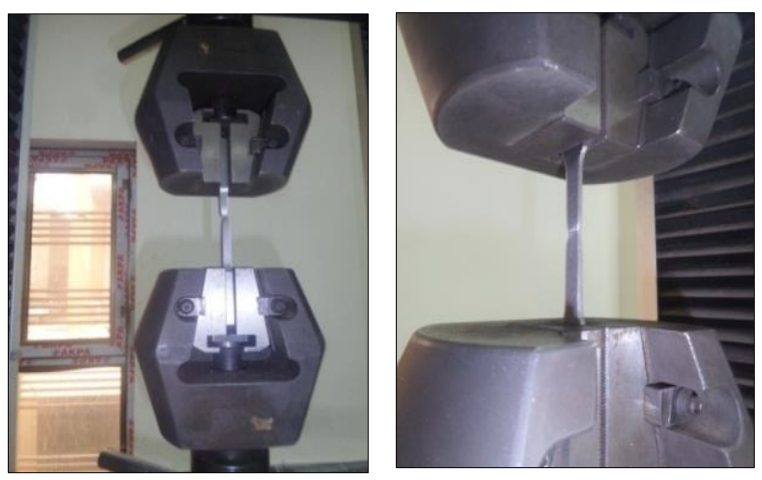

Fig. 1. Tensile Strength Test for Steel Plates

\subsection{CFRP Laminate}

The type of CFRP used to strengthen the girders is sika-warp-230 c produced by Sika Corporation, as shown in Figure (2) and Table (2), where the latter is about the properties of CFRP provided according to manufacturer data sheet attached to the CFRP laminate.

Table 2. CFRP Properties

\begin{tabular}{|c|c|}
\hline Properties & Sika Warp 230-c \\
\hline Tensile Strength (MPa) & 4300 \\
\hline E-Modulus (GPa) & 238 \\
\hline $\begin{array}{c}\text { Elongation At Break } \\
\text { (Strain)\% } \%\end{array}$ & 1.8 \\
\hline $\begin{array}{c}\text { Thickness (mm) } \\
\text { Density (g/cm3) }\end{array}$ & 1.131 \\
\hline
\end{tabular}
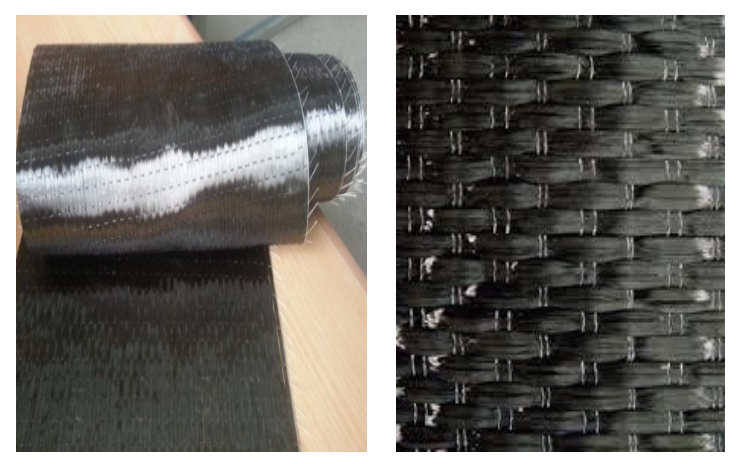

Fig. 2. CFRP Laminate

\subsection{Adhesive epoxy}

The suitable adhesive material used with the carbon fiber strips is Sikadur ${ }^{\circledR}-330$, as shown in Figure (3). This type of adhesive consists of two parts: part A, resin, which is white and part $\mathrm{B}$, hardener, which is grey. The main properties of the adhesive are provided according to manufacturer data sheet attached to the adhesive package, as shown in Table (3).

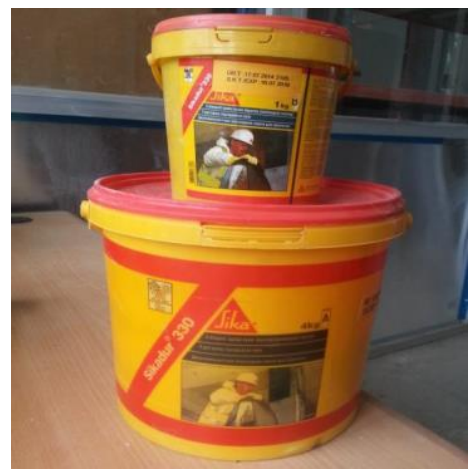

Fig. 3. Sikadur ${ }^{\circledR}-330$ Container

Table 3. Sikadur ${ }^{\circledR-} 330$ Properties

\begin{tabular}{|c|c|}
\hline Properties & Sikadur ${ }^{\circledR}$ - 330 \\
\hline Density (kg/l) at $+23^{\circ} \mathrm{C}$ & $\begin{array}{c}\text { Parts A+B mixed : } \\
1.31\end{array}$ \\
\hline Tensile Strength $(\mathrm{MPa})$ & 30 \\
\hline E-Modulus $(\mathrm{GPa})$ & Flexural : 3.8 \\
\hline Elongation At Break (Strain)\% & 0.9 \\
\hline Setting Time (Minute) at $35^{\circ} \mathrm{C}$ & 30 \\
\hline
\end{tabular}

\section{Type and details of the plate girders}

Two types of plate girders have been used in this study. The first type is without web opening whereas the second is with a web opening. The second type is further sub-divided into two types: square and diamond web opening. The length of web opening is $240 \mathrm{~mm}$ and the shear stresses in the webs are relatively low in comparison to the bending stresses in the flanges. As a result, the $2 \mathrm{~mm}$ web plate is generally chosen to be much thinner than the flanges which are $(6 \mathrm{~mm})$ [7]. For more details about the girders, consider Figure (4) and Table (4) where three of the girders are reference 
whereas the other four are strengthened girders with different patterns of CFRP laminate.
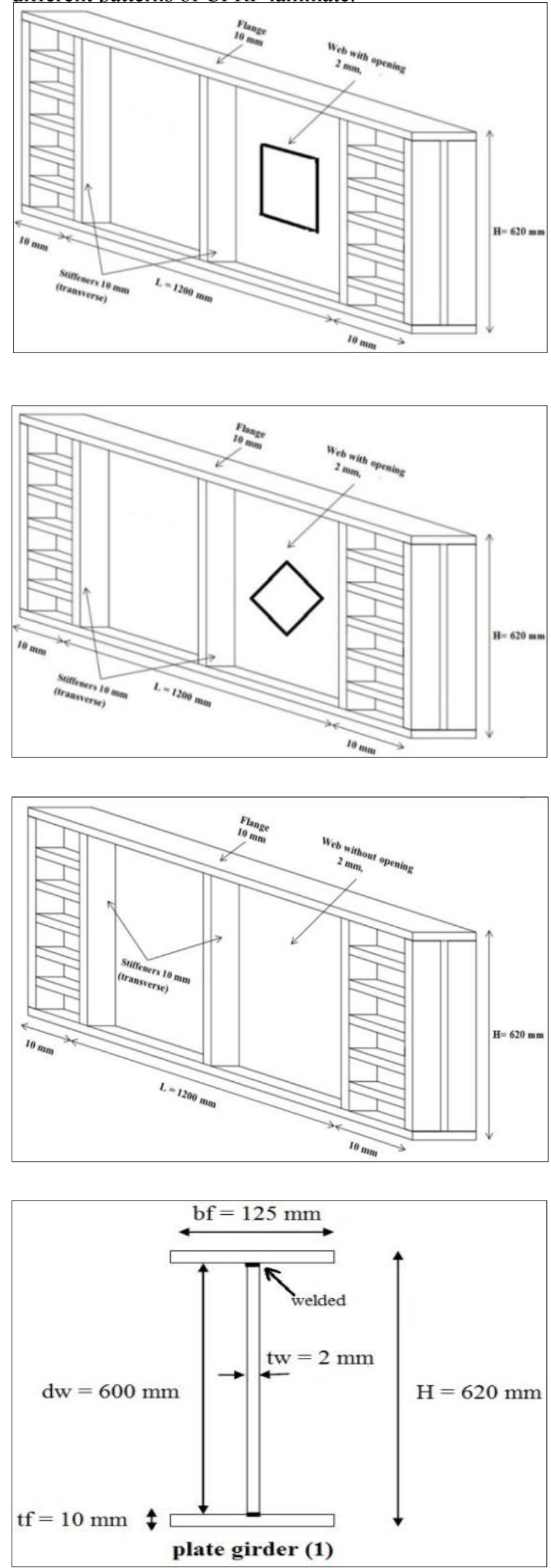

Fig. 4. Details of Plate Girders
Table 4. Details of Plate Girders in (mm)

\begin{tabular}{|c|c|c|c|c|c|c|c|c|c|c|}
\hline 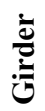 & 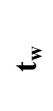 & 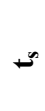 & $=$ & $=$ & ــ & $\sigma$ & $\sigma$ & $\vec{\partial}^{3}$ & ริ & 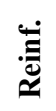 \\
\hline 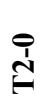 & $N$ & $\stackrel{\circ}{1}$ & ㅇ & $\cong$ & 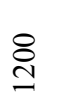 & 8 & 8 & ঃ্ & - & 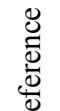 \\
\hline 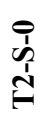 & $N$ & $\stackrel{\circ}{ }$ & ㅇ & $\cong$ & $\underset{\beth}{\stackrel{్}{~}}$ & \& & 8 & ৪্ল & - & 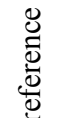 \\
\hline $\begin{array}{l}\bar{n} \\
\dot{\omega} \\
\tilde{n}\end{array}$ & $N$ & 으 & $ㅇ$ & $\cong$ & $\underset{\beth}{\stackrel{\Xi}{二}}$ & \& & : & 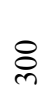 & - & 总 \\
\hline $\begin{array}{l}\tilde{y} \\
\hat{n} \\
\tilde{H}\end{array}$ & $N$ & ㅇ & 임 & $\stackrel{\overbrace{}}{\beth}$ & $\underset{\Xi}{\stackrel{\Xi}{二}}$ & \& & 8 & 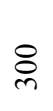 & - & 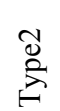 \\
\hline 竞 & $N$ & $\stackrel{0}{1}$ & ㅇ & $\cong$ & 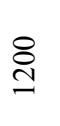 & ¿ & \& & \&్ల & - & 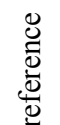 \\
\hline & $N$ & 으 & ㅇ & $\cong$ & $\underset{\nearrow}{\stackrel{\overbrace{}}{二}}$ & \&્ర & \& & : & - & $\sum_{\vec{E}}^{\vec{D}}$ \\
\hline ָ̃ & $N$ & ㅇ & ㅇ & $\cong$ & ¿્વ & 8 & 8 & ষ্ল & - & 岕 \\
\hline
\end{tabular}

\section{Types of strengthening}

Type1 includes strengthening the web of girders using CFRP strips of $10 \mathrm{~mm}$ width from two sides. The first side is parallel to the flanges while the second is perpendicular to flanges, as it is used in (T2-D-1), (T2-S-1) girders shown in figure (5). 

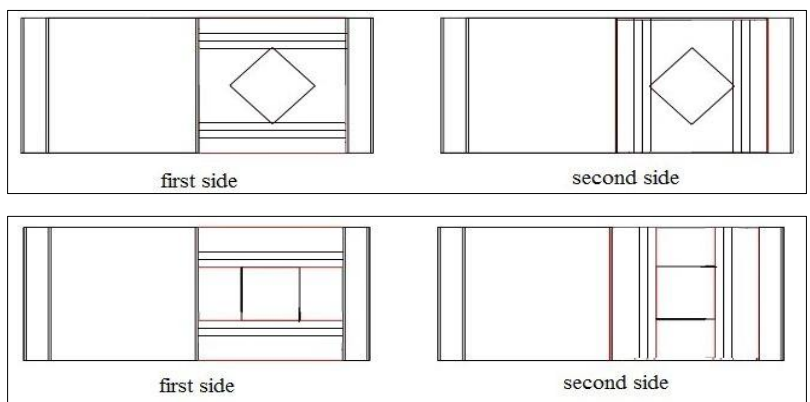

Fig. 5. Type (1) of strengthening (T2-D-1) and (T2-S-1) Girders

Type2 involves strengthening the web of the girders via CFRP strips of $10 \mathrm{~mm}$ width from two sides. In the first side, the strengthening is diagonally put along the tension at $\Theta 45$ whereas in the second side, it is put diagonally along the compression at $\Theta 135$. Cases in point are the ones used in (T2-D-2) and (T2-S-2) girders; consider Figure (6).
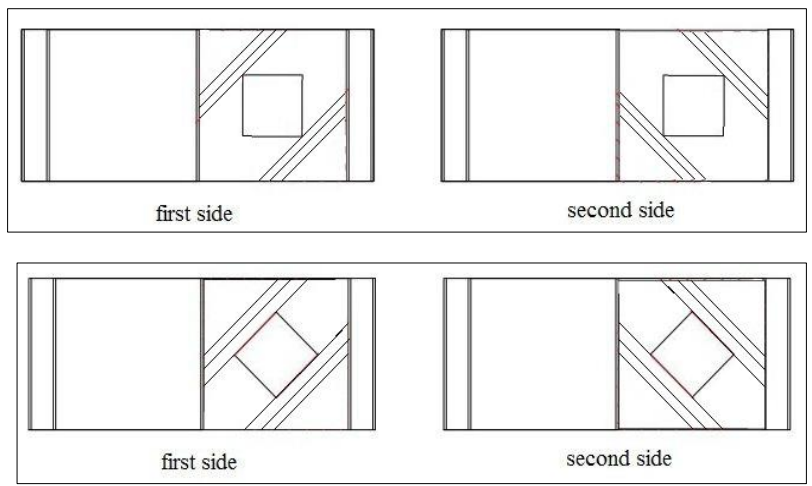

Fig. 6. Type (2) of Strengthening (T2-D-2) and (T2-S-2) Girders

\section{Testing procedure instrumentation}

and

All plate girders were simply supported by a pin and roller over $1200 \mathrm{~mm}$ span. The girders were tested up to the failure mode under the action of applied load at the mid span of the girder. Such an application helps ensure that each of two panels equally have half of the applied load; see Figure (7). The maximum load capacity of the tested machine (Avery) is 120 tons and the deflections of all girders were measured by a dial gauge of 0.01 accuracy installed at the mid span under the girders.
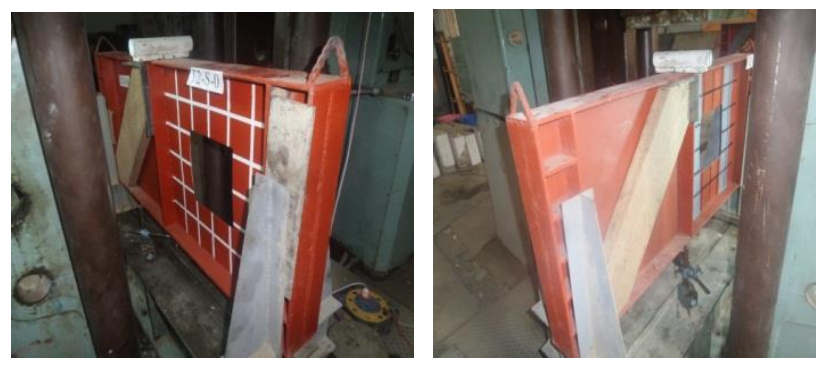

Fig. 7. Test Setup for a sample of Plate Girder

\section{Evaluation of ultimate shear strength}

\subsection{Girders without web opening:}

The ultimate shear strength can be obtained as follows:

The critical shear stress $\left(\tau_{\mathrm{cr}}\right)$ in this stage is given through adopting Gardiff Method:

$$
\tau_{\mathrm{cr}}=\mathbf{K}_{\mathrm{s}} * \frac{\pi^{2} * E}{12\left(1-v^{2}\right)} *\left(\frac{t_{w}}{d}\right)^{2}
$$

Where:

$\left(\mathrm{K}_{\mathrm{s}}\right)$ : the shear buckling coefficient given by:

$$
\begin{aligned}
& \mathbf{K}_{\mathbf{s}}=\mathbf{5 . 3 5}+\mathbf{4}\left(\frac{d}{a}\right)^{2} \quad \text { where }\left(\frac{d}{a}\right) \geq 1 \\
& \mathbf{K}_{\mathbf{s}}=\mathbf{5 . 3 5} *\left(\frac{d}{a}\right)^{2}+\mathbf{4} \quad \text { where }\left(\frac{d}{a}\right) \leq 1
\end{aligned}
$$

Where:

(d): Depth of the girder in mm;

$\left(\mathrm{t}_{\mathrm{w}}\right)$ : web thickness in $\mathrm{mm}$;

(a): Clear distance of the web plate between the vertical stiffeners in $\mathrm{mm}$;

(E): Modulus of elasticity in MPa; and

(v): poisons ratio.

$\sigma_{\mathrm{yt}}=\sqrt{\sigma_{y w}{ }^{2}+\tau_{\mathrm{cr}}{ }^{2}\left(\frac{9}{4} \sin ^{2} 2 \theta-3\right)}-\frac{3}{2} \tau_{c r} * \sin 2 \theta$

Where:

$$
\theta=\frac{2}{3} \tan ^{-1}\left(\frac{d}{a}\right)
$$

$\left(\sigma_{y w}\right)$ : the tensile stress of web in MPa.

$$
\begin{aligned}
& \mathbf{M}_{\mathrm{pf}}=\frac{1}{4} * \sigma_{y f} * b_{f} * t_{f}^{2} \\
& \mathbf{M}_{\mathrm{p}} *=\frac{M_{p f}}{d^{2} * \sigma_{\mathrm{yw}} * \mathrm{t}_{\mathrm{w}}} \\
& \mathbf{V}_{\mathrm{cr}}=\boldsymbol{\tau}_{\mathrm{cr}} * d * \boldsymbol{t}_{\boldsymbol{w}} \\
& \mathrm{V}_{\text {post }}=\sigma_{\mathrm{yt}} * t_{w} * \sin ^{2} \theta(\mathrm{d} * \cot \theta-\mathbf{a})+4 \mathrm{~d} * \mathrm{t}_{\mathrm{w}} * \\
& \sin \theta \sqrt{\sigma_{y w} * \sigma_{\mathrm{yt}} * M_{\mathrm{p}}} \\
& \mathbf{V}_{\text {ult }}=\mathbf{V}_{\text {cr }}+\mathbf{V}_{\text {post }}
\end{aligned}
$$

Where:

$\left(\sigma_{y f}\right)$ : the tensile stress of flange in $\mathrm{MPa}$;

$\left(\mathrm{b}_{\mathrm{f}}\right)$ : flange width; and

$\left(t_{f}\right)$ : flange thickness.

\subsection{Girders with web opening}

$$
k_{0}=k s\left(1-\frac{d h}{d}\right)
$$

Where: 
$\left(\mathrm{K}_{\mathrm{s}}\right)$ : the shear buckling coefficient from equation (2); and

(dh): the opening diameter or length.

$$
\begin{gathered}
\left(\tau_{\mathrm{cr}}\right)_{\mathrm{o}}=\mathrm{K}_{\mathrm{o}} \frac{\pi^{2} * \mathrm{E}}{12\left(1-\mathrm{v}^{2}\right)} *\left(\frac{\mathrm{tw}}{\mathrm{d}}\right)^{2} \\
\sigma_{\mathrm{yt}}=\sqrt{\sigma_{y w}{ }^{2}+\left(\tau_{\mathrm{cr}}\right)_{o}{ }^{2}\left(\frac{9}{4} \sin ^{2} 2 \theta-3\right)}-\frac{3}{2}\left(\tau_{\mathrm{cr}}\right)_{o} * \sin 2 \theta
\end{gathered}
$$

Where:

$$
\begin{aligned}
& \left(\mathbf{V}_{\mathrm{cr}}\right)_{0}=\left(\boldsymbol{\tau}_{\mathrm{cr}}\right)_{o} * \boldsymbol{d} * \boldsymbol{t}_{\boldsymbol{w}} \text {; and } \\
& V_{\text {post }}=\sigma_{\mathrm{yt}} * t_{w} * \sin ^{2} \theta(d * \cot \theta-a)+4 d * t_{w} * \\
& \sin \theta * \sqrt{\sigma_{y w} * \sigma_{\mathrm{yt}} * \mathbf{M}_{\mathrm{p} *}} \\
& \left(\mathrm{~V}_{\text {post }}\right)_{0}=0.5 * \mathrm{~V}_{\text {post }} \\
& (\text { Vult })_{0}=(\text { Ver })_{0}+(\text { Vpost })_{0}
\end{aligned}
$$

\section{Test results}

Figure (8) shows the load deflection curves for the tested girders (T2-0) without web opening and (T2-D-0) with diamond web opening as reference girders. Moreover, the (T2-D-1) and (T2-D-2) girders were strengthened by CFRP strips. Results have revealed that the diamond web opening decreases the ultimate shear load resistance to $44 \%$, whereas the girders (T2-D-1) and (T2-D-2) which were strengthened by CFRP strips, as in Type 1 and Type 2, show a higher stiffener and a high load than that of (T2-D-0).

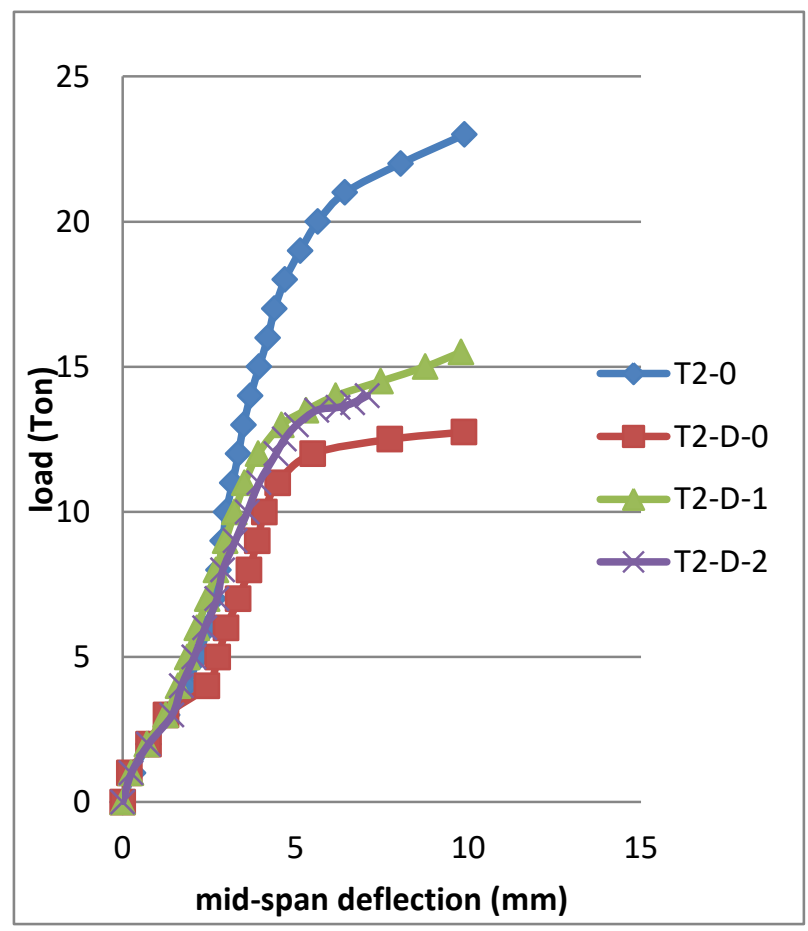

Fig. 8. Load -Deflection Curves for (T2-0), (T2-D-0), (T2-D$1)$, and (T2-D-2)
Figure (9) shows the load deflection curves for the tested girders (T2-0) without web opening and (T2-S-0) with square web opening where both represent the reference girders. In addition, the girders (T2-S-1) and (T2-S-2) were strengthened by CFRP strips. Results have shown that the square web opening decreases the ultimate shear load resistance to $38 \%$, while the girders (T2-S-1) and (T2-S-2), which were strengthened by CFRP strips, as in Type 1 and Type 2, show higher stiffener and a high load than that of (T2-S-0).

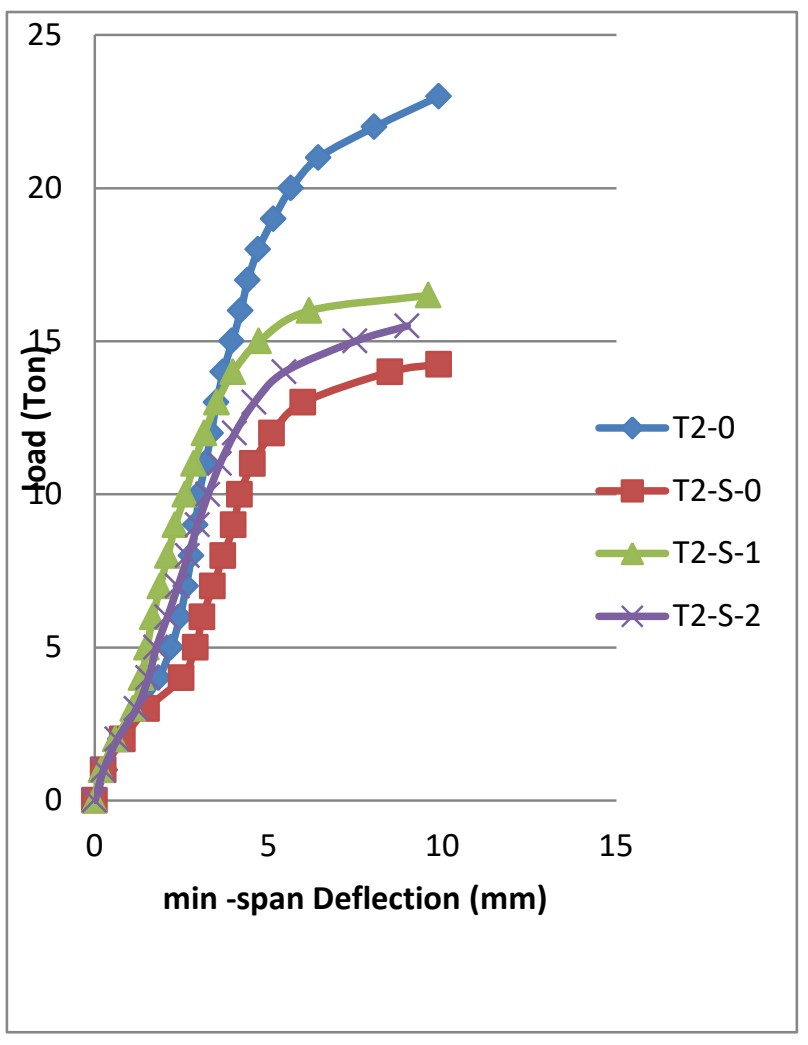

Fig. 9. Load -Deflection Curves for (T2-0), (T2-S-0), (T2-S-1), and (T2-S-2)

In the vein, the CFRP strips-strengthened girders were all painted in light grey. Besides, the test was conducted on only one panel of girders whereas the second panel was diagonally strengthened by a woodmade stiffener. This is because the girder is symmetrical in shape and has two panels. As it was previously mentioned, each panel should equally carry half of the applied load. Accordingly, and economically speaking, there is no need for the two panels to be tested. This is because both the first and second panels of the girders share common results and behavior. Figure (10) portrays the failed mode of all girders after the tests. In this respect, the researchers compared between the analytical and experimental results. In addition, the ultimate shear load was compared with its reference girder, as illustrated Table (5). 


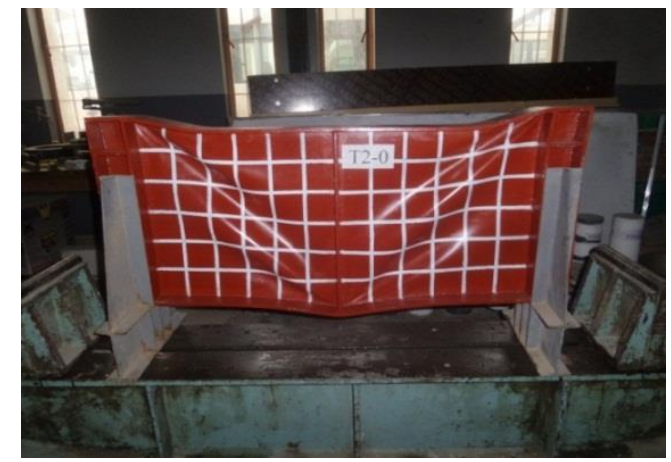

A. A Reference Plate Girder without a Web Opening

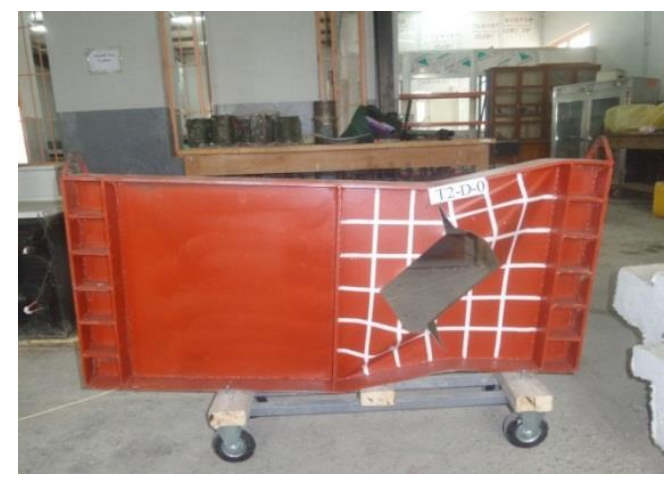

B. A Reference Plate Girder with a Web Opening (T2-D-0)

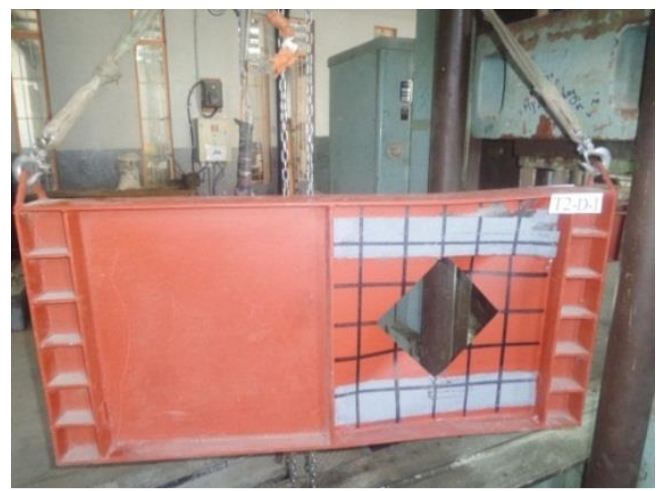

C. A Plate Girder with a Web Opening (T2-D-1)

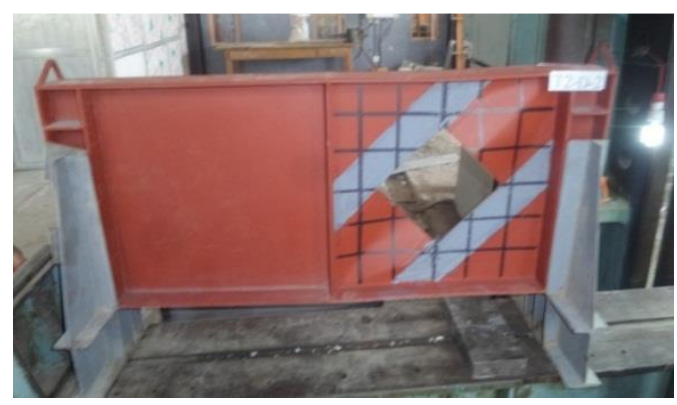

D. A Plate Girder with a Web Opening (T2-D-2)

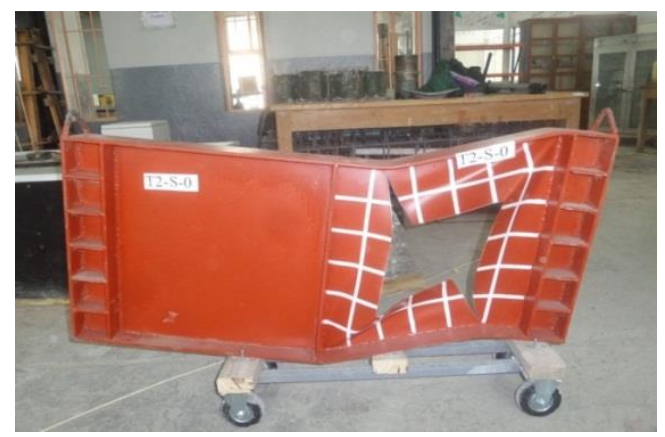

E. A Reference Plate Girder with a Web Opening (T2-S-0)

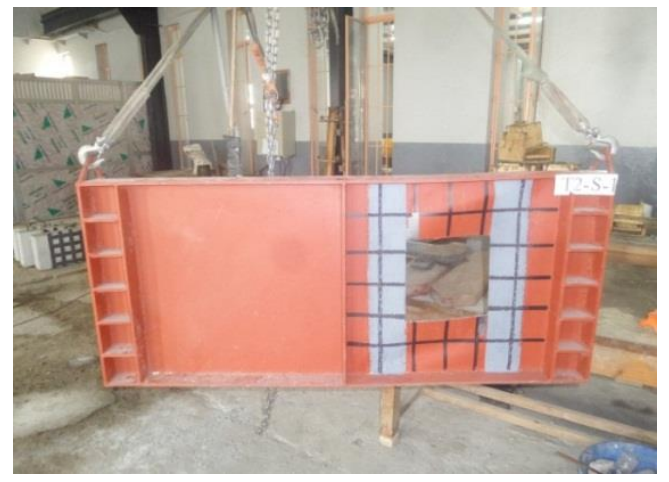

F. A Plate Girder with a Web Opening (T2-S-1)

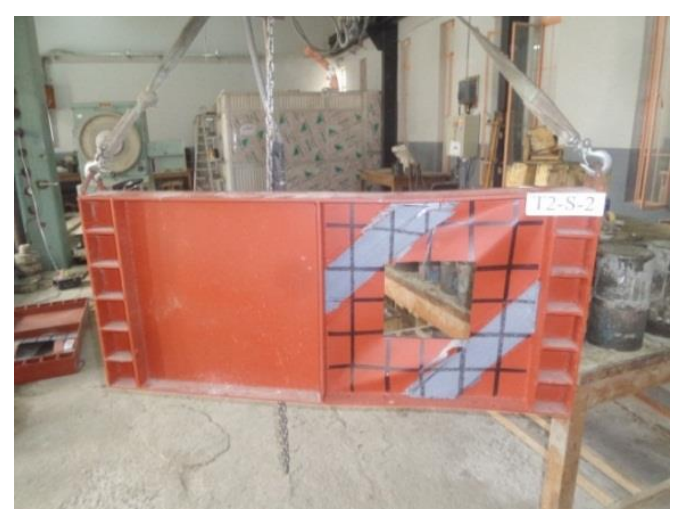

G. A Plate Girder with a Web Opening (T2-S-2)

Fig. 10. The Tested Plate Girder after the Failure Mode 
Table 5. The Analytical and Experimental Ultimate Shear Load for the Girders in comparison to their Reference Girders

\begin{tabular}{|c|c|c|c|c|}
\hline 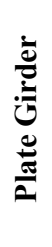 & 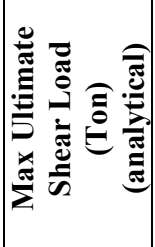 & 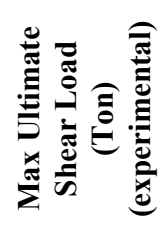 & 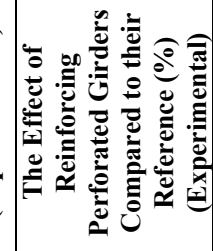 & 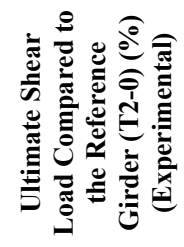 \\
\hline 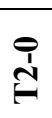 & 25.25 & 23 & - & - \\
\hline $\begin{array}{l}\stackrel{1}{1} \\
\stackrel{1}{\tilde{T}}\end{array}$ & 12.7 & 12.75 & - & -10.25 \\
\hline 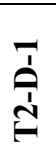 & 14.2 & 15.5 & 21.5 & -7.5 \\
\hline $\begin{array}{l}\tilde{\Lambda} \\
\stackrel{\Lambda}{\tilde{I}}\end{array}$ & 12 & 14 & 9.8 & -9 \\
\hline 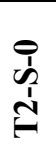 & 13.48 & 14.25 & - & -8.75 \\
\hline 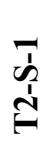 & 14.21 & 16.5 & 15.7 & -6.5 \\
\hline 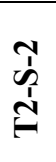 & 9.63 & 15.5 & 8.7 & -7.5 \\
\hline
\end{tabular}

\section{Conclusions}

1- The ultimate shear resistance has decreased by about (38\%) for the girder with a square opening of $40 \%$ side length of the web depth compared to the girder without a web opening;

2- The ultimate shear load has decreased by about (44.5\%) for the girder with a diamond opening of $40 \%$ side length of the web depth compared to the girder without a web opening;

3- The ultimate shear load for the girders with a square web opening strengthened by CFRP strips was higher than the reference girder with a square web opening. The ranges of the ultimate shear obtained are $8.7 \%$ and $15.7 \%$, depending on the orientation of the CFRP strips;

4- The ultimate shear load for the girders with a diamond web opening strengthened by CFRP strips are higher than that of the reference girder with a diamond web opening. The ranges of the ultimate shear obtained are $9.8 \%$ and $21.5 \%$, depending on the orientation of the CFRP strips;

5- The experimental results of the plate girders have shown the applicability and effectiveness of the strengthening technique used in girders with a web opening. Furthermore, the technique is shown to increase the shear strength of these girders; and

6- The most effective form used to strengthen the web opening of plate girders was type (1). This type was strengthened by CFRP strips that were parallel and perpendicular to their flanges.

\section{References}

1. K. Abed, MSc Thesis, Structural Engineering Department, University of Technology, Baghdad, pp.3, (2015)

2. M. S. Abdul Gabar, MSc Thesis, Structural Engineering Department, University of Technology, Baghdad, pp.3 (2012)

3. N. C. Hagen, P. K. Larsen, A. Aalberg, Journal of constructional Steel Research 65, 1, 142-50 (2009)

4. M. j. Hamoodi, I. N. Korkess, K. F. Sarsam, The 6th Engineering Conference, College of Engineering, Baghdad University 1, 1-17 (April 2009)

5. Web site www.steel-insdag.org/teaching material /chapter28.pdf

6. K. Rockey, H. Evans, D. porter, A design method for predicting the collapse behavior of plate girders, proceeding institution of civil engineers, part2, 85112 (1978)

7. Z. Al-azzawi, T. Stratford, M. Rotter, L. Bisby, Conference: Response of Structures under Extreme Loading- Protect, The University of Edinburgh UK., 1-11 (January 2015) 


\section{Notations}

a: The clear of the web plate between vertical stiffeners;

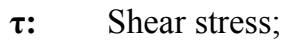

tw: Thickness of the web;

d: Depth of girder;

MPf: Plastic moment capacity of the flange plate;

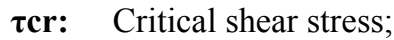

dh: Diameter of the opening;

oyw: Tensile yield stress of the web; and

бyt: Tensile membrane stress at yield.

ko: Buckling coefficient for a perforated web;

ks: $\quad$ Shear buckling coefficient;

$\boldsymbol{\theta}: \quad$ The angle of inclination of the membrane stress;

бyf: $\quad$ Tensile yield stress of the flange;

Vpost: Post buckling shear force;

Vult.: Ultimate shear strength;

Vcr.: Critical buckling shear force;

Mp *: Non-dimensional flange strength parameter;

ccrv: Shear buckling stress of plate girder reinforced by CFRP;

Dv: Flexural rigidity of plate girder bonded CFRP laminate;

бy: $\quad$ Yield stress of steel material; and

бu: Ultimate stress of steel material. 